\title{
INTEGRASI PENDIDIKAN LALU LINTAS DI SEKOLAH
}

\author{
Ine Kusuma Aryani \\ Universitas Muhammadiyah Purwokerto \\ subuhanggoroupi@gmail.com
}

\begin{abstract}
ABSTRAK
Traffic and road transport have a strategic role to support national development and integration as part of efforts to promote public welfare as mandated by the 1945 Constitution of the Republic of Indonesia. As part of a transportation system that has to be developed its potential and role to create security, safety, discipline and smooth traffic and road transportation in order to support economic development and the development of science and technology, in Law number 22 of 2009 concerning traffic and road transportation, it is explicitly stated that there is a sharpening of the formulation of principles and objectives, which is in addition to creating traffic and road transportation that is safe, secure, discipline, smooth and integrated with other transportation models, the Law aims at supporting the national economy, realizing public welfare and national unity, and upholding the dignity of the nation. Therefore, aspects of security and safety are a concern in realizing ethics and cultures in a cross-disciplined manner, through efforts of guidance and education from an early age in elementary schools in a sustainable manner so that it is expected to reduce the number of traffic accidents which tend to be dominated by school age. One reason is due to the many violations and less knowledge of legal awareness in traffic. Ethics and cultural of traffic is implemented in the teaching and learning process that is integrated through 2013 curriculum since early age with techniques and methods of learning that are conducive and correct with teaching materials for elementary school so they understand traffic procedures that can benefit themselves and others, and in the end can realize security, safety, order and smooth traffic.
\end{abstract}

Keywords: traffic education, ethics education and curriculum 2013.

\section{PENDAHULUAN}

Masalah keamanan berlalu lintas dalam masyarakat berkaitan dengan penggunaan lalu lintas sebagai sarananya, keamanan berlalu lintas adalah keamanan terhadap manusia, kendaraan, jalan maupun lingkungan. UU No. 22/2009 tentang Lalu Lintas dan Angkutan Jalan menagamanatkan bahwa peran dan fungsi polisi dibidang lalu lintas adalah Pendidikan Masyarakat Lantas (education), Rekayasa Lantas (engineering), Penegakan hukum (law 
enforcement), Registrasi dan Identifikasi pengemudi dan kendaraan bermotor (registration and identification), dan sebagai pusat K3l (Komando, Kendali, Koordinasi dan Informasi) Lalu lintas.

Fungsi dan peran tersebut bertujuan untuk mewujudkan keamanan, keselamatan, ketertiban dan kelancaran lalu lintas, meminimalisir korban fatalitas sebagai akibat terjadinya kecelakaan lalu lintas, kepatuhan masyarakat terhadap hukum dan peraturan lalu lintas, serta meningkatkan pelayanan masyarakat dibidang lalu lintas. Sejalan dengan perkembangan masyarakat saat ini maka kebutuhan sarana dan prasarana yang terkait dengan transportasi guna mendukung produktivitas di berbagai bidang yang menggunakan sarana jalan raya semakin meningkat. Hal tersebut memberi dampak positif dan negatif.

Dampak positif menyangkut aspek efisiensi waktu, namun di sisi lain juga membawa dampak negatif yaitu timbulnya permasalahan-permasalahan lalu lintas yang terus tumbuh dan berkembang. Permasalahan lalu lintas dipandang member kontribusi yang cukup besar pada kecelakaan lalu lintas. Hasil studi terungkap 42\% dari 1260 kasus kecelakaan lalu lintas yang terjadi di Jawa Tengah tahun 2016 pada umumnya di awali dengan pelanggaran lalu lintas oleh pengemudi, sisanya sebanyak $58 \%$ disebabkan oleh kondisi kendaraan jalan dan alam. Kecelakaan lalu lintas walaupun tidak dominan, pengemudi tetap member kontribusi bagi timbulnya kecelakaan lalu lintas yang disebabkan oleh faktor bukan manusia.

Diperlukan kegiatan pengendalian lali lintas secara menyeluruh dan terpadu tidak cukup hanya dengan penegakan hukum semata, namun perlu melakukan upaya yang ditunjang oleh seluruh komponen bangsa, adanya peran aktif dari masyarakat dalam mewujudkan rasa kesadaran dan disiplin dalam melakukan aktivitas di jalan raya. Hal ini sesuai dengan amanat pasal 258 UU No. 22/2009, bahwa "masyarakat wajib berperan serta dalam pemeliharaan sarana dan prasarana, pengembangan disiplin dan etika berlalu lintas dan berpartisipasi dalam pemeliharaan keamanan, keselamatan dan kelancaran lalu lintas dan angkutan jalan".

Namun kenyataan di lapangan masyarakat masih banyak yang belum memahami untuk ikut serta berpartisipasi melaksanakan disiplin dan etika berlalu 
lintas, motor ugal-ugalan, lampu merah masih tancap gas, tabrak lari, bobot berat truk yang tidak sepadan dengan kekuatan bobot beratnya, dan kasus lainnya yang menyebabkan terjadinya kecelakaan lalu lintas.

Berdasarkan masalah tersebut, maka diperlukan model pengintegrasian Pendidikan Keselamatan lalu Lintas untuk tingkat satuan pendidikan dimulai dari tingkat Sekolah Dasar/Madrasah Ibtidaiyah (SD/MI) maupun Sekolah Menengah Pertama/ Madrasah Tsanawiyah (SMP/MTs) dan Sekolah Menengah Atas/Madrasah Aliyah (SMA/MA).

\section{Model Pengintegrasian Pendidikan Lalu Lintas}

Disiplin berlalu lintas merupakan salah satu pencerminan dari disiplin nasional yang menunjukkan harga diri atau martabat sebuah bangsa. Maka dari itu selayaknya Kepolisian Negara Republik Indonesia (Polri) lebih mengedepankan aspek pendidikan kepada masyarakat berkaitan dengan disiplin berlalu lintas. Strategi dan program untuk mewujudkan dan memelihara keamanan, keselamatan, ketertiban dan kelancaran lalu lintas melalui kegiatan "Road Safety". Road Safety merupakan program kegiatan untuk melindungi pemakai jalan raya serta terwujudnya keselamatan di jalan. Implementasi kegiatan road safety dilakukan melalui: Polsana (Polisi Sahabat Anak), PKS (Patroli Keamanan Sekolah), Traffic Police Goes to Campus, Safety Riding, Kampanye Keselamatan Lalu Lintas, TMC (Traffic Management Center), Sekolah mengemudi, Saka Bhayangkara Lantas, Traffic Board, Taman Lalu Lintas, Oprasi Kepolisian, Penegakan Hukum.

Kegiatan road safety pada dasarnya lebih menekankan pada model pendidikan ekstrakurikuler, dimana sasaran pendidikan terhadap beberapa kelompok yang bersifat terbatas. Sementara amanat UU no. 22/2009 pada pasal 258 tersebut lebih mengedepankan kewajiban setiap orang mampu memahami secara keseluruhan dari aspek kognitif, afektif dan motorik. Oleh karena itu untuk membangun pemahaman secara gradual tidah cukup pengetahuan lalu lintas tersebut diajarkan dalam bentuk ekstrakurikuler, namun harus lebih mendasar melalui pendidikan intrakurikuler dan dikenalkan melalui mata pelajaran tertentu, strategi integrasi dilakukan melalui telaah Standar kompetensi (SK) dan 
Kompetensi Dasar (KD) yang mengandung etika dan kedisiplinan. Salah satu SK dan KD yang bermuatan kedua hal tersebut adalah mata pelajaran Pendidikan Kewarganegaraan (PKn).

Secara konsep, dapat dikemukakan bahwa PKn dalah pengorganisasian dari disiplin ilmu-ilmu sosial dan humaniora dengan penekanan pada pengetahuan dan kemampuan dasar tentang hubungan antara warganegara dan warganegara dengan Negara yang dilandasi keimanan dan ketakwaan terhadap Tuhan yang Maha Esa, nilai luhur dan moral budaya bangsa, memiliki rasa kebangsaan (nasionalisme) yang kuat dengan memperlihatkan keragaman agama, sosiokultural, bahasa dan suku bangsa dan memiliki jiwa demokratis yang diharapkan dapat diwujudkan dalam perilaku sehari-hari. Dengan kata lain bahwa konten atau materi PKn di Indonesia terdiri dari beberapa disiplin ilmu yang memerlukan pengorganisasian materi secara sistematis dan pedagogik, seperti IImu Hukum, Politik, Tata Negara, Humaniora, Moral Pancasila, Psikologi, Nilainilai Budi Pekerti dan disiplin ilmu lainnya.

Pendidikan kewarganegaraan (PKn) adalah nama salah satu mata pelajaran sebagai muatan wajib dalam kurikulum Pendidikan Dasar dan Menengah (Pasal 37 Ayat 1 UU SPN). Selanjutnya dalam Lampiran Peraturan Menteri Pendidikan Nasional Nomor 22 Tahun 2006 Tentang Standar isi ditegaskan bahwa PKn termasuk cakupan kelompok mata pelajaran Kewarganegaraan dan kepribadian, dimaksudkan untuk peningkatan kesadaran dan wawasan peserta didik akan status, hak dan kewajibannya dalam kehidupan bermasyarakat, berbangsa dan bernegara, serta peningkatan kualitas dirinya sebagai manusia. Selain itu perlu pula ditanamkan kesadaran wawasan kebangsaan, jiwa patriotism dan bela Negara, penghargaan terhadap hak asasi manusia, kemajemukan bangsa, pelestarian lingkungan hidup, kesetaraan gender, demokrasi, tanggung jawab sosial, ketaatan pada hukum, ketaatan membayar pajak, dan sikap serta perilaku berlalu lintas.

Tujuan model pengintegrasian ini sebagai salah satu panduan bagi guru SD/MI, SMP/MTs, SMA/MA dalam rangka mengintegrasian pendidikan lalu lintas dalam pembelajaran PKn. Secara khusus dengan menggunakan model ini para guru memperoleh pemahaman dalam hal: a) menganalisis substansi dan 
hubungannya dengan pendidikan lalu lintas sebagai pesan-pesan konstitusional dengan standar isi, standar kompetensi dan kompetensi dasar PKn; b) mengintegrasikan aspek dan indikator pendidikan lalu lintas ke dalam standar kompetensi dan kompetensi dasar PKn; c) menyusun model integrasi pendidikan lalu lintas dalam silabus pembelajaran PKn; d) menyusun model integrasi pendidikan lalu lintas ke dalam rencana pelaksanaan pembelajaran (RPP) PKn.

Manfaat menggunakan model ini bagi guru dapat melaksanakan hal-hal: a) membangun kehidupan sekolah sebagai lingkungan sadar berlalu lintas dengan mengambangkan kebiasaan disiplin lalu lintas dalam kehidupan sehari-hari; b) membina warga sekolah agar memiliki kompetensi kewarganegaraan yang meliputi pengetahuan kewarganegaraan (civic knowledge), sikap dan watak kewarganegaraan (civic dispositions), dan keterampilan kewarganegaraan (civic skill); c) meningkatkan mutu penyelenggaraan pendidikan di sekolah melalui pendidikan lalu lintas yang diintegrasikan secara sistematis dan sistemik dalam mata pelajaran Pendidikan Kewarganegaraan.

Ruang lingkup model pengintegrasian ini berpijak pada pemahaman pendidikan keselamatan lalu lintas yang ditinjau dari dimensi politik, sosiologi, ekonomi dan hukum yang dikemas secara pedagogis dengan pengembangan nilai-niolai pendidikan lalu lintas sebagai berikut:

\begin{tabular}{|c|c|}
\hline Aspek dan Indikator & $\begin{array}{l}\text { Materi Pendidikan Keselamatan Lalu } \\
\text { Lintas }\end{array}$ \\
\hline $\begin{array}{l}\text { 1. Hukum: } \\
\text { a. Menaati rambu-rambu } \\
\text { lalulintas } \\
\text { b. Menaati marka jalan } \\
\text { c. Menaati isyarat pengatur } \\
\text { lalu lintas } \\
\text { d. Melengkapi pengamanan } \\
\text { diri dalam berlalu lintas } \\
\text { 2. Sosiologi: } \\
\text { a. Member kesempatan }\end{array}$ & $\begin{array}{l}\text { 1. Pengertian } \\
\text { a. Lalu Lintas } \\
\text { b. Rambu-rambu lalu lintas } \\
\text { c. Marka jalan, alat pemberi } \\
\text { isyarat pengatur lalu lintas } \\
\text { d. Pengamanan diri sebagai } \\
\text { pengaturan jalan } \\
\text { e. Tata cara berlalu lintas dengan } \\
\text { benar } \\
\text { 2. Dua belas gerakan pengaturan lalu }\end{array}$ \\
\hline
\end{tabular}




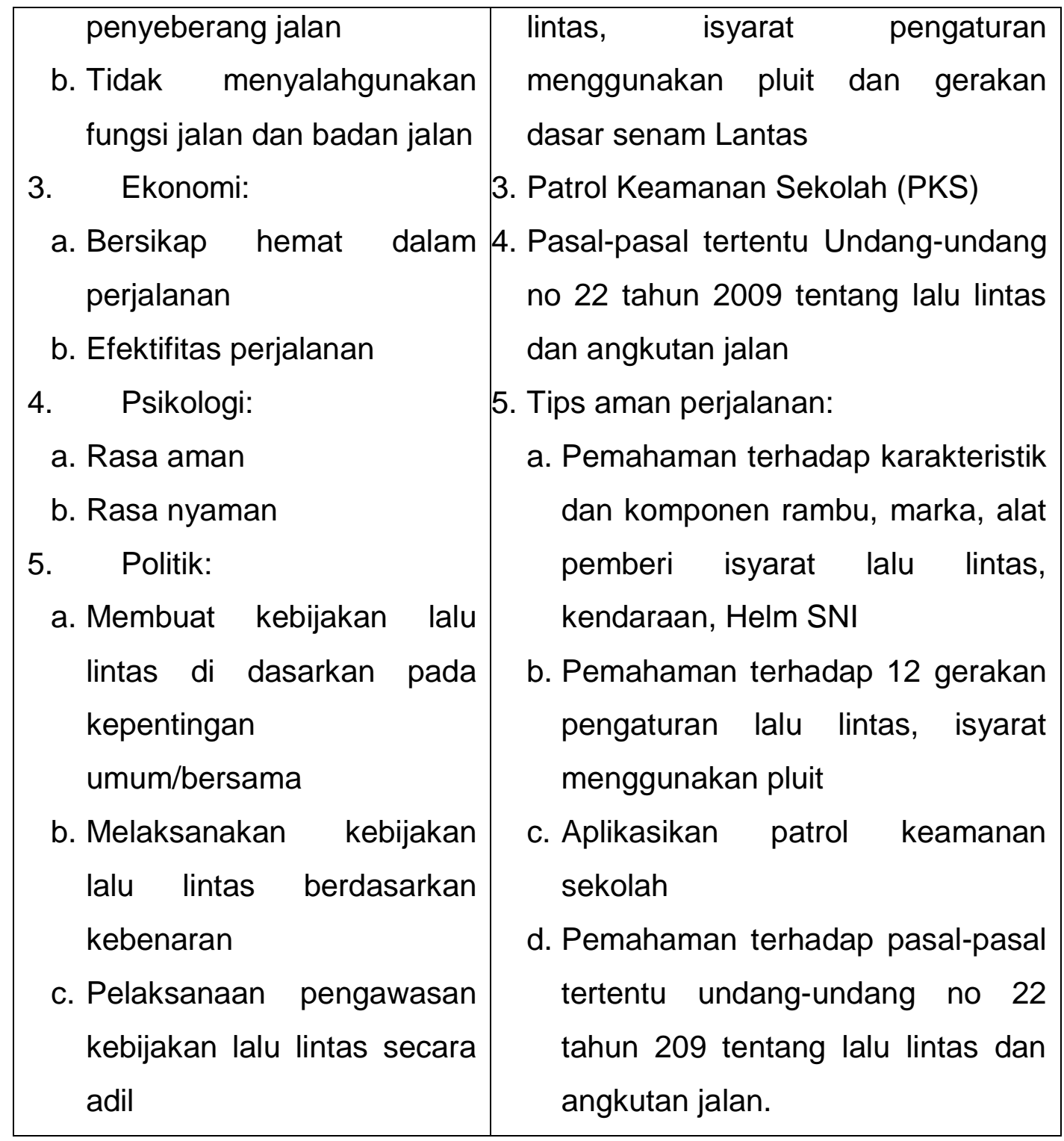

Berdasarkan ruang lingkup tersebut, pengembangan model pengintegrasian mencakup:

1. Penyusunan model integrasi pendidikan lalu lintas pada standar isi

2. Penyusunan dan pengembangan integrasi pendidikan lalu lintas pada silabus

3. Penyusunan dan pengembangan integrasi pendidikan lalu lintas pada rencana pelaksanaan pembelajaran (RPP).

\section{Pembahasan Contoh Model Integrasi}


a. Integrasi Pendidikan lalu Lintas pada Standar Kompetensi tentang Sistem Hukum dan Peradilan Nasional (Di SD Kelas 5 semester 1 Bab 2 Peraturan Perundang-undangan)

Sistem hukum nasional adalah keseluruhan kaidah-kaidah hukum yang mengatur tata perbuatan dalam masyarakat untuk menciptakan ketertiban dan ketentraman. Sistem hukum nasional disebut juga tata hukum nasional.

Ditinjau dari sudut bentuknya, tata hukum nasional terdiri dari (a) hukum tertulis dan (b) hukum tidak tertulis. Hukum tertulis di bagi lagi ke dalam hukum tertulis yang dikodifikasikan dan hukum tertulis yang tidak dikodifikasikan,

Kitab Undang-undang Hukum Pidana dan Kitab Undang-undang Hukum Perdata merupakan contoh hukum tertulis yang dikodifikasikan (dikompilasi dalam sebuah Kitab). Hukum tertulis yang tidak dikodifikasikan adalah sejumlah kaidahkaidah hukum yang terdapat atau tersebar dalam sejumlah peraturan perundangundangan. Ditinjau dari sudut isinya, tata hukum nasional terdiri dari (a) hukum publik yang mengatur kepentingan publik (umum) dalam hubungan antara warga Negara dengan Negara dan (b) hukum privat yang mengatur kepentingan orang perseorangan dalam buhungan anatar individu yang satu dengan individu lainnya.

Ditinjau dari sudut tugas dan fungsinya, hukum tata hukum nasional terdiri dari (a) hukum material yang berisi perintah dan larangan dan (b) hukum formal yang berisi tata cara melaksanakan dan memperhatikan hukum material.

Ditinjau dari sudut tempat berlakunya, tata hukum nasional terdiri dari (a) hukum lokal yang hanya berlaku di daerah tertentu saja dan (b) hukum nasional yang berlaku pada seluruh wilayah negara.

Menurut waktu berlakunya, hukum nasional terdiri dari (a) hukum yang berlaku saat ini yang disebut hokum positif (ius constitutum), (b) hukum yang berlaku pada waktu yang akan dating (ius constituendum), dan (c) hukum antarwaktu yang mengatur peristiwa yang menyangkut hukum yang berlaku saat ini dan hukum yang berlaku pada masa lalu.

Ditinjau dari sunjek yang diaturnya, hukum nasional terdiri dari (a) hukum satu golongan yang hanya berlaku bagi satu golongan terttentu saja, (b) hukum semua golongan yang berlaku bagi semua golongan warga negara, dan (c) hokum 
antar golongan yang mengatur 2 (dua) pihak yang masing-masing tunduk pada hukum yang berbeda.

Pada prinsipnya, hukum merupakan sekumpulan tata perbuatan manusia yang berisi perintah atau larangan yang pelaksanaannya dapat dipaksakan oleh penguasa (Negara) dengan ancaman sanksi

Berkenaan dengan tata perbuatan manusia dalam berlalu lintas, terdapat pula sekumpulan peraturan hukum yang mengaturnya, yang sekarang ini diatur dalam UU Nomor 22/2009 tentang Lalu Lintas dan Angkutan Jalan. Peraturan hukum ini termasuk ke dalam ranah hukum publik, yakni mengatur kepentingan umum dalam bidang berlalu lintas dan angkutan jalan. Undang-undang ini dibuat dengan tujuan agar tercipta suatu kondisi kelancaran, ketertiban, ketertiban, keamanan, dan keselamatan dalam berlalu lintas dan angkutan jalan. Untuk mencapai tujuan tersebut, dibuatlah peranturan-peraturan berlalu lintas yang harus ditaati dan/atau dipatuhi oleh setiap pengguna jalan. Di antara peranturanperaturan dalam berlalu lintas ini adalah perintah-perintah dan/atau laranganlarangan sebagaimana disimbolkan melalui tanda rambu-rambu lalu lintas, dan 12 (dua belas) gerakan pengaturan lalu lintas. Oleh sebab itu, menjadi keharusan hukum bagi setiap pengguna jalan untuk memahami dan mematuhi ini dapat dipaksakan dengan ancaman sanksi dalam arti bahwa barangsiapa yang melanggar maka terhadapnya dapat dikenakan sanksi berupa sanksi pidana denda dan/atau kurungan.

Ketentuan-ketentuan pidana berkenaan dengan lalu lintas diatur dalam pasal 273 sampai dengan pasal 317 UU No. 22/2009 tentang Lalu Lintas dan Angkutan jalan. Contoh ketentuan pidana antara lain pasal 288 ayat (2): "Setiap orang yang mengemudikan kendaraan bermotor di jalan yang tidak dapat menunjukkan SIM yang sah dipidana kurungan paling lama 1 (satu) bulan dan/atau denda paling banyak Rp. 250.000,00 (dua ratus lima puluh ribu rupiah)". Tata cara penindakan pelanggaran lalu lintas dan angkutan jalan dilakukan oleh pengadilan di lingkungan peradilan umum.

b. Integrasi Pendidikan Lalu Lintas pada Standar Kompetensi tentang Persamaan Kedudukan Warga Negara Dalam Berbagai Aspek Kehidupan (SD semester 2 Bab 3 Kebebasan Berorganisasi dan Bab 4 Keputusan Bersama) 
Indonesia terdiri dari berbagai macam suku bangsa dengan menganut berbagai keyakinan/agama, berbagai golongan dan memiliki keanekaragaman adat dan budaya. Keragaman masyarakat Indonesia ini (adat istiadat, tata cara, bahasa, kesenian, kerajinan, keterampilan daerah, dII) merupakan cirri khas yang memperkaya nilai-nilai kehidupan bangsa Indonesia. Oleh karena itu sisi positif dari keanekaragaman tersebut harus selalu dipelihara dan dikembangkan dengan tetap mempertahankan nilai-nilai luhur bangsa Indonesia sendiri.

Keragaman dalam berbagai aspeknya ini tidak menjadi alasan untuk membeda-bedakan perlakuan terhadap warga negara kecuali menurut peraturan perundang-undangan. "Segala warga negara bersamaan kedudukannya di dalam hukum dan pemerintahan dan wajib menjunjung hukum dan pemerintahan itu dengan tidak ada kecualinya" (Pasal 27 ayat (1) UUD RI tahun 1945). Dengan demikian, setiap warga negara memiliki hak dan kewajiban yang sama dalam hukum dan pemerintahan dalam arti tidak ada perlakuan khusus yang diskriminatif karena perbedaan-perbedaan ras, agama, gender, golongan, budaya dan suku.

Penerapan prinsip persamaan kedudukan setiap warga negara ini dapat diimplementasikan dalam ranah kehidupan berlalu lintas. Setiap pengguna jalan memiliki kedudukan, hak dan kewajiban yang sama. Setiap orang berhak menikmati fasilitas jalan sesuai fungsinya menurut undang-undang. Setiap pengguna jalan memiliki kewajiban yang sama untuk mematuhi segala peraturan lalu lintas dan angkutan jalan.

Setiap orang yang menggunakan jalan wajib (a) berperilaku tertib, dan/atau (b) mencegah hal-hal yang dapat merintangi, membahayakan keamanan dan keselamatan lalu lintas dan nagkutan jalan, atau yang dapat menimbulkan kerusakan jalan.

Setiap orang yang mengemudikan kendaraan bermotor wajib:

(1) Mengemudikan kendaraannya dengan wajar dan penuh konsentrasi

(2) Mengutamakan keselamatan pejalan kaki dan pesepedah

(3) Mematuhi ketentuan tentang persyaratan teknis dan laik jalan

(4) Mematuhi ketentuan rambu-rambu, marka jalan, alat pemberi isyarat, gerakan lalu lintas, berhenti dan parkir, peringatan dengan bunyi dan sinar, kecepatan 
maksimal dan minimal, dan/atau tata cara penggandengan dan penempatan dengan kendaraan lain

(5) Menunjukkan STNKB atau STCKB, SIM, uji berkala, dan tanda lain yang syah

(6) Mengenakan sabuk keselamatan bagi pengemudi roda empat dan penumpang di sampingnya

(7) Mengenakan helm SNI bagi pengemudi sepeda motor

(8) Pengemudi sepeda motor tanpa kereta samping dilarang membawa penumpang labih dari a (satu) orang

Pengendara kendaraan tidak bermotor dilarang:

(1) Dengan sengaja membiarkan kendaraannya ditarik oleh kendaraan bermotor dengan kecepatan yang dapat membahayakan keselamatan

(2) Mengangkut atau menarik benda yang dapat merintangi atau membahayakan pengguna jalan lain; dan/ atau

(3) Menggunakan jalur jalan kendaraan bermotor jika disediakan jalur jalan khusus

Pengemudi kendaraan bermotor yang terlibat kecelakaan lalu lintas, wajib:

(1) Menghentikan kendaraan yang dikemudikannya

(2) Memberi pertolongan kepada korban

(3) Melaporkan kecelakaan kepada kepolisian terdekat

Setiap orang yang mendengar, melihat, dan/atau mengetahui terjadinya kecelakaan lalu lintas wajib:

(1) Memberikan pertolongan kepada korban

(2) Melaporkan kecelakaan tersebut kepada kepolisian dan/atau

(3) Memberikan keterangan kepada kepolisian

Pesepeda dilarang membawa penumpang kecuali jika sepeda tersebut dilengkapi dengan tempat penumpang

Pengendara gerobak atau kereta dorong yang berjalan beriringan harus memberikan ruang yang cukup bagi kendaraan lain untuk mendahului

Pengemudi kendaraan bermotor umum angkutan orang dilarang:

(1) Memberhentikan kendaraan selain di tempat yang ditentukan

(2) Mengetem selain di tempat yang telah ditentukan 
(3) Menurunkan penumpang selain di tempat pemberhentian dan/atau di tempat tujuan tanpa alasan yang patut dan mendesak, dan /atau

(4) Melewati jaringan jalan selain yang ditentukan dalam izin trayek

Pejalan kaki berhak:

(1) Atas ketersediaan fasilitas pendukung yang berupa trotoar, tempat penyeberangan, dan fasilitas lain

(2) Mendapatkan prioritas pada saat menyeberang di tempat penyeberangan

(3) Dalam hal tidak ada tempat penyeberangan, pejalan kaki berhak menyeberang di tempat yang dipilih dengan memperhatikan keselamatan dirinya

Pejalan kaki wajib;

(1) Menggunakan bagian jalan yang diperuntukkan bagi pejalan kaki atau jalan yang paling tepi

(2) Menyeberang di tempat yang telah ditentukan

(3) Dalam hal tidak terdapat tempat penyeberangan, pejalan kaki wajib memperlihatkan keselamatan dan kelancaran lalu lintas

(4) Pejalan kaki penyandang cacat harus mengenakan tanda khusus yang jelas dan mudah dikenali pengguna jalan lain.

Skala prioritas atau perlakuan khusus di bidang lalu lintas dan angkutan jalan hanya dibeikan kepada segolongan orang yang karena keadaannya memerlukan pelayanan khusus. Perlakuan khusus di bidang lalu lintas, anak-anak, wanita hamil, dan orang sakit. Perlakuan khusus ini meliputi: (a) aksesibilitas, (b) prioritas pelayanan, dan (c) fasilitas pelayanan.

c. Integrasi Pendidikan Lalu Lintas pada Standar Kompetensi tentang Sikap Positif terhadap Pancasila sebagai Ideologi Terbuka (SD Semester 1 Bab 1 Keutuhan Negara Kesatuan Republik Indonesia-NKRI)

Hakikat Pancasila sebagai sumber nilai tidak lepas dari kedudukannya sebagai dasar negara dan pandangan hidup. Sejak penetapan Pancasila sebagai dasar negara, maka saat itu nilai-nilai kehidupan bernegara harus mengacu pada dasar negara tersebut. Oleh karena itu ketentuan peraturan penyelenggaraan negara tidak boleh bertentang dengan nilai Pancasila termasuk (aspek hukum). UU Lalu 
Lintas No 22/ 2009 merupakan produk hukum yang mengikat setiap warga negara, memiliki konsekuensi bahwa setiap pemakai jalan raya mempunyai kewajiban menaati rambu-rambu, marka, dan isyarat pengatur lalu lintas. Kebiasaan setiap warga menaati segala peraturan lalu lintas lambat laun mengalami menjadi kebiasaan yang berulang dan mengalami kristalisasi menjadi budaya tertib berlalu lintas

Implementasi pelaksanaan Pancasila dalam kehidupan bernegara dan berbangsa merupakan nilai luhur yang digali dari budaya masyarakat sendiri (aspek sosiologi), sehingga menjadi nilai dasar dalam membangun ide dan berprilaku. Menghormati hak-hak orang lain dengan tidak menyalah gunakan fungsi jalan untuk kepentingan pribadi dan member kesempatan penyeberang jalan merupakan wujud aktualisasi Pancasila yang mampu dijadikan landasan instrumental dan praktik bermasyarakat (aspek sosiologis).

Ketaatan menjalankan aturan lalu lintas memiliki dampak terhadap lingkungan jalan, yang pada tahap berikutnya masyarakat pengguna jalan merasa aman dan nyaman (aspek psikologis). Pembangunan manusia Indonesia untuk menjalan peraturan dan tertib berlalu lintas harus dijiwai oleh nilai-nilai Pancasila. Oleh karena itu perumusan kebijakan harus mempunyai ranah menjunjung tinggi hakhak warganegara secara seimbang dan penuh rasa keadilan (aspek politik).

Pancasila sebagai pandangan hidup bangsa Indonesia, berarti bahwa nilai-nilai yang terkandung dalam Pancasila dijadikan tuntunan dan pegangan dalam mengatur sikap dan tingkah laku manusia Indonesia, dalam hubungannya dengan Tuhan, masyarakat dan alam semesta.

Jadi hakikat Pancasila sebagai sumber nilai berarti Pancasila dijadikan landasan dalam kehidupan bermasyarakat, berbangsa dan berbegara, dengan demikian setiap tindakan warganegara, penyelenggaraan pemerintahan sesuai dengan ketentuan aturan yang ada, termasuk Implementasi UU no 22 /2009 tentang Lalu Lintas dan Angkutann Jalan (aspek hukum dan sosiologis)

Nilai adalah sesuatu yang berharga, yang berguna, yang indah, yang memperkaya batin, yang menyadarkan manusia dan harkat dan martabatnya. Oleh karena itu nilai berhubungan dengan tingkah laku atau berbagai aspek kehidupan manusia dalam prakteknya Pancasila merupakan nilai dan cita-cita 
bangsa Indonesia yang tidak dipaksakan dari luar, melainkan digali dan diambil dri kekayaan rohani, moral dan budaya masyarakat kita sendiri.

Nilai-nilai dasar Pancasila sendiri adalah sesuatu yang universal, yang pada dasarnya merupakan penjelmaan dari suara nurani tentang kewajiban ber-Tuhan sebagai sesuatu hak yang paling asasi, penghargaan terhadap nilai-nilai kemanusiaan, indahnya kebersamaan dengan persatuan, menghagai dan mendahulukan atau prokerakyatan dan hikmah serta mendeklarasikan pula penghargaan, penghormatan dan perjuanagan untuk keadilan yang egalitarian. (Murdiona, 2010) menggolongkan nilai menjadi tiga, yaitu nilai dasar, nilai instrumental dan nilai praksis. Nilai dasar yang menjadi sumber etika bagi bangsa Indonesia adalah nilai-nilai yang terkandung dalam Pancasila.

Dalam pelaksanaannya nilai-nilai dasar Pancasila dijabarkan dalam nilai instrumental. Nilai instrumental ialah nilai yang menjadi pedoman pelaksanaan dari nilai dasar. Nilai dasar belum dapat bermakna sepenuhnya apabila nilai dasar tersebut belum memiliki formulasi serta parameter atau ukuran yang jelas dan konkrit. Apabila nilai instrumental itu berkaitan dengan tingkah laku manusia dalam kehidupan sehari-hari maka nilai tersebut akan menjadi norma moral. Tetapi jika nilai instrumental itu merupakan suatu arahan kebijaksanaan berupa peraturan perundang-undangan yang berlaku, sehingga dapat juga dikatakan bahwa nilai instrumental itu merupakan suatu eksplisitasi dari nilai dasar. Contoh konkrit dari nilai instrumental tersebut dalam bidang lalu lintas, tercermin dalam UU no 22/2009 tentang lalu lintas dan nagkutan jalan, dimana implementasi dari UU tersebut mengarahkan masyarakat untuk berprilaku disiplin selama berkendaraan di jalan raya, dengan memperhatikan keamanan berkendaraan (safety road) sehingga keselamatan di jalan dapat diperoleh. Kesadaran berprilaku disiplin apabila dirasakan sebagai bentuk tanggung jawab, secara akumulasi mengalami internalisasi dan kristalisasi menjadi etika budaya berlalu lintas.

Pancasila sebagai sumber dan paradigm pembangunan nasional berarti Pancasila sebagai kerngka berpikir, bahwa pembangunan nasional di segala bidang termasuk bidang lalu lintas harus berdasarkan pada nilai-nilai Pancasila. Pembangunan bidang ekonomi, berarti ekonomi yang mementingkan rakyat (ekonomi kerakyatan), bukan dalam ekonomi kapitalis yang cenderung berdampak 
persaingan tidak sehat. Komponen besar dalam ekonomi terletak pada aktivitas distribusi baik barang maupun orang melalui fasilitas jalan raya, pada saat inilai menaati isyarat dan rambu-rambu lalu lintas menjadi penting untuk menjaga keamanan dan keselamatan berlalu lintas.

\section{SIMPULAN}

Model pengintegrasian pendidikan Lalu Lintas pada mata pelajaran Pendidikan Kewarganegaraan merupakan wahana untuk membantu guru SD/MI, SMP/MTs, SMA/MA, dan SMK/MAK dalam melaksanakan kegiatan pembelajaran di sekolah, baik di dalam maupun di luar kelas.

Kedudukan guru sebagai motivator dan fasilitator menuntut adanya kompetensi guru dalam merencanakan pembelajaran secara optimal dengan mengacu pada Standar Kompetensi dan Kompetensi Dasar mata pelajaran Pendidikan Kewarganegaraan. Untuk menghasilkan kegiatan pembelajaran yang baik dan benar diperlukan perencanaan pembelajaran yang baik dan benar pula dengan mengacu pada peraturan yang telah ditentukan dan menggunakan strategi, pendekatan dan model-model pemebelajaran inovatif dan relevan.

Strategi dasar pembelajaran Pendidikan Kewarganegaraan berupa variasi interaksi pembelajaran di dalam kelas sebagai peletakan dasar kompetensi dan elemen esensial terkait dengan berbagai dimensi tujuan. Dengan adanya model pengintegrasian pendidikan lalu lintas pada mata pelajaran Pendidikan Kewarganegaraan ini, diharapkan dapat meningkatkan kualitas perencanaan, pelaksanaan serta penilaian proses dan hasil pembelajaran di dalam dan di luar kelas.

\section{DAFTAR PUSTAKA}

Kepolisian Negara Republik Indonesia, 2010, Bahan Pengajaran Pendidikan Etika dan Budaya Berlalu Lintas, Jakarta

Mansyhur Effendi, A. 2015. Perkembangan Dimensi Hak Azasi manusia (HAM) dan Proses Dinamika Penyusunan Hukum HAM, Bogor: Ghalia Indonesia

Peraturan Pemerintah nomor 19 tahun 2005 tentang Standar nasional Pendidikan

Permendiknas RI Nomor 41 Tahun 2007 tentang Standar Proses untuk Satuan Pendidikan Dasar dan Menengah 
Tilaar H.A.R, 2010, Perubahan Sosial dan Pendidikan pengantar Pedagogik Transformatif untuk Indonesia, Jakarta: Grasindo

Undang-undang Republik Indonesia Nomor 2 Tahun 2002 tentang Kepolisian Republik Indonesia

Undang-undang Republik Indonesia nomor 20 Tahun 2003 tentang Sistem Pendidikan Nasional

Undang-undang Republik Indonesia Nomor 22 Tahun 2009 tentang Lalu Lintas dan angkutan Jalan

Undang-Undang Dasar Republik Indonesia Tahun 1945 